$\xi=-$ 줄

\title{
Temporal monitoring of Ghamu bar glacial lakes using remote sensing and GIS
}

\author{
Alamgeer Hussain ${ }^{1}$, Dilshad Bano ${ }^{1}$ \\ ${ }^{\text {I }}$ PMAS-Arid Agriculture University Rawalpindi \\ *Corresponding author E-mail:alamgeerh@gmail.com
}

\begin{abstract}
The trends of glacial lakes formation and glacial lake outburst flooding events have been increased across Himalayan Karakorum Hindu Kush $(\mathrm{HKH})$ ranges during last decade due to increase in global warming. This research is addressing the temporal monitoring of ghamu bar glacial lakes using remote sensing and GIS. Landsat images of 1990, 2000, 2010 and 2015 were used to map temporal glacial lakes using normalized difference water index (NDWI) index. The results of normalized difference water index were validated through modified normalized difference water index and field photographs. Temporal variability shows that, glacier lake area has been increase from 1990 to 2015. In 1990 total area of lake was $0.052 \mathrm{sq}$, which further increased 0.0423 in 1995 than it decreases to 0.314 in 2000 due to detached of debris cover moraine from glacier tongue and it reach $0.0846 \mathrm{sq} . \mathrm{km}$ in 2005 . The area gradually increased up to 0.1296 sq.km in 2010 and it goes up to 0.157 sq.km 2015. The overall increase in area are expanding at an accelerated rate in past two decades, indicating that Darkut glacier is more vulnerable toward climate change through increase in size and volume ofghamu bar glacial lakes. There is need for vigilance in monitoring of ghamu bar glacial lake through high resolution remote sensing data and development of Geo-database enabling more details about past and future lakes behaviors toward climate change impacts.
\end{abstract}

Keywords:NDWI; Remote Sensing; MNDWI; Geo Database.

\section{Introduction}

Remote Sensing data is very common in use to map glaciers, monitoring of glacier changes in a specific time period and many other features details can be extracted using different techniques (Gao et al., 2016). Normalized Difference Water Index (NDWI) and Modified-NDWI (MNDWI) are among common indices used to extract lake area using Landsat satellite imagery. These indices proved to be useful due to NIR band's low and blue band's high reflectance (Huggel et al., 2004). Remote sensing is one of cost affective and quicker technique than traditional field investigation to monitoring and mapping of wide scale area of remote glaciers and glacial lakes. Optical satellite like Landsat sensor (Frazier and page 2000, Mool et al. 2001, Huggel et al. 2003, Kääb, A., et al. 2002 and Haq, M. Anul, et al 2012) has been used for mapping and monitoring of glacial lakes. Glacial lakes of Himalaya, karakoram and Hindu Kush (HKH) ranges have been mapped and delineated (Randhawa 2005, Ashraf, A. et al. 2011 and LU, A. X. et al 2005) using water indices. Temporal glacial lake surface was delineated and mapping through automatic detection method using normalized difference water index (NDWI) by (bolch et al 2008,). Normalized difference water index (NDWI) was developed by McFeeters 1996 to delineate water bodies and enhance their presence in satellite images. NDWI is calculated using normalized ratio of green and Near Infrared.

The objective of this study to describe temporal change of area coverage of ghamu bar glacial lake using Landsat images of $1990,1995,2000,2010$ and 2015 couple with ground survey and field photographs. Ground survey and lake assessment conducted using different approaches include visual observations, the study of site geology and physical settings of the landscape. The lake dimensions i.e. length and width measurements, analyze the strength of moraine lake by observation of seepage points and outflow through seepage, soil and debris material composition and the physiography of outlet of the lake are critical parameters to be consider. Bathymetric data collection using Boat, Sounder method and traditional approach of Pole and Rope method with GPS device is the only way to measure lake depth to estimate the Lake volume in remote glacial lakes, which is beneficial to know the potential of flash flood in case of lake outburst (Khanal et al., 2015).

The freely availability of Landsat images with suitable spatial and temporal resolution and broad coverage are very useful for to monitor of glacial lakes behaviors and glacial lake outburst flood (GLOF) (Wessel's et. al, 2002 and Racoviteanu et. al, 2008). Gilgit-Baltistan has witnessed around 35 GLOF events in past 200 years UNDP, 2007. In 1994, a huge GLOF occurred in Sosot village, Gupis valley and a lake was formed due to accumulation of blocked Ghizar River. This event took five lives and caused heavy destruction to crop land and other property. In same valley another GLOF event occurred in 1999 at Gupis Khalti village which also blocked Ghizar River and created a $1.5 \mathrm{~km}$ long lake known as "Khalti Lake" 3 which was breached after few months and caused huge destruction in the downstream settlements. In 2007, 2008 and 2009 two GLOF events from Ghulkin glacier caused destruction of property and blocked Karakorum Highway (PMD, 2016). Oneof the major devastatingGLOF event occurred from ghamu bar glacial lake washed out two houses, destroyed agriculture and road infrastructure in downstream of Yasin valley. 
Ghamu bar glacial lake is locate at south east of Darkut village and 140km ground distance from Gilgit city. The lake is located in Hindu Kush mountains Yasin valley district Ghizar, Pakistan. The lake is formed at the tongue of Darkut glacier. There is no supra glacier drainage on the surface but glacial melt water flow through in-glacier paths. The main valley glacier is fed by two main tributaries; avalanches from the slopes also contribute to a positive mass balance of a glacier. In general avalanches also provide a plenty of debris load to the glacier surface near lateral moraines while almost glacier is clean and free of debris. Height of the glacier ice at snout is $39 \mathrm{~m}$ and distance of glacier ice from new terminal moraine is $151 \mathrm{~m}$ (FOCUS, 2013). Geographically ghamu bar lake is Lies between the latitudes $36^{\circ} 37^{\prime \prime}-36^{\circ} 44^{\prime \prime} \mathrm{N}$ and longitudes $73^{\circ} 24^{\prime \prime}-73^{\circ} 27^{\prime \prime} \mathrm{E}$.

\section{Material and methods}

\subsection{Study area}

Darkut Glacial Lake which is also known as Ghamu Bar Glacial Lake is located at the altitude of about 9026ft above sea level. The Glacier is extended in length about $3900 \mathrm{~m}$ and average width is $644 \mathrm{~m}$. Total area covered by Glacier ice is approx.2.51 sq.km. Snout of glacier is partially debris covered and saturated crevasses; however, the debris is saturated towards lateral moraines. Seasonal snow on the mountains contributes a lot in water runoff.

Ghamu bar Lake is formed at the terminus of the glacier ice; ice melted water is accumulated by the old terminal lateral moraines. Main source of water into the Lake is the Darkut glacier in the west of the lake. Due to western lies position of the glacier, it goes through high melting, which may accelerate the melting of glacier. The lake is spread over $0.48 \mathrm{~km}(475.17 \mathrm{~m})$ in length and $0.30 \mathrm{~km}(304.22 \mathrm{~m})$ wide with approximate depth of 81 meters (PMD, 2013).

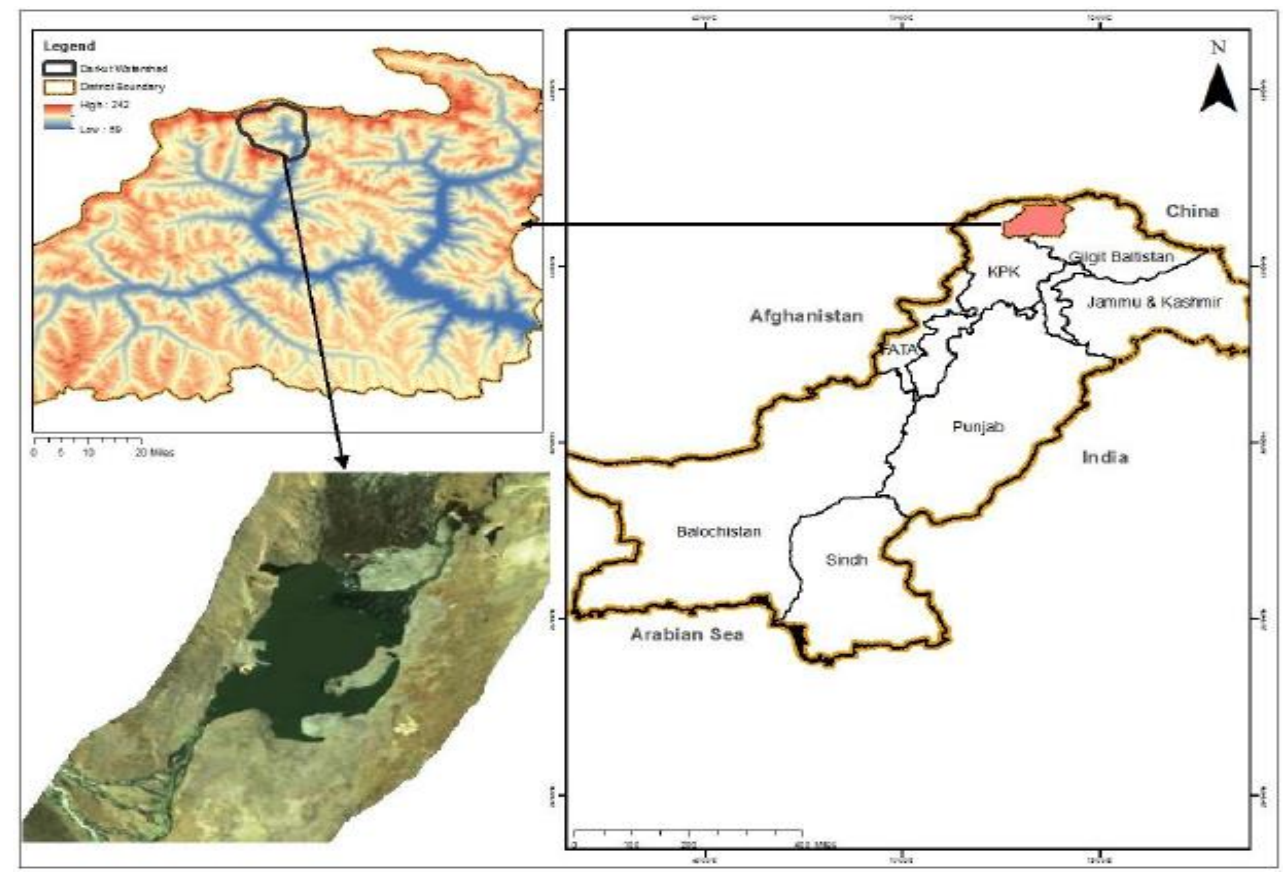

Fig. 1: Study Area.

\subsection{Work flow diagram}

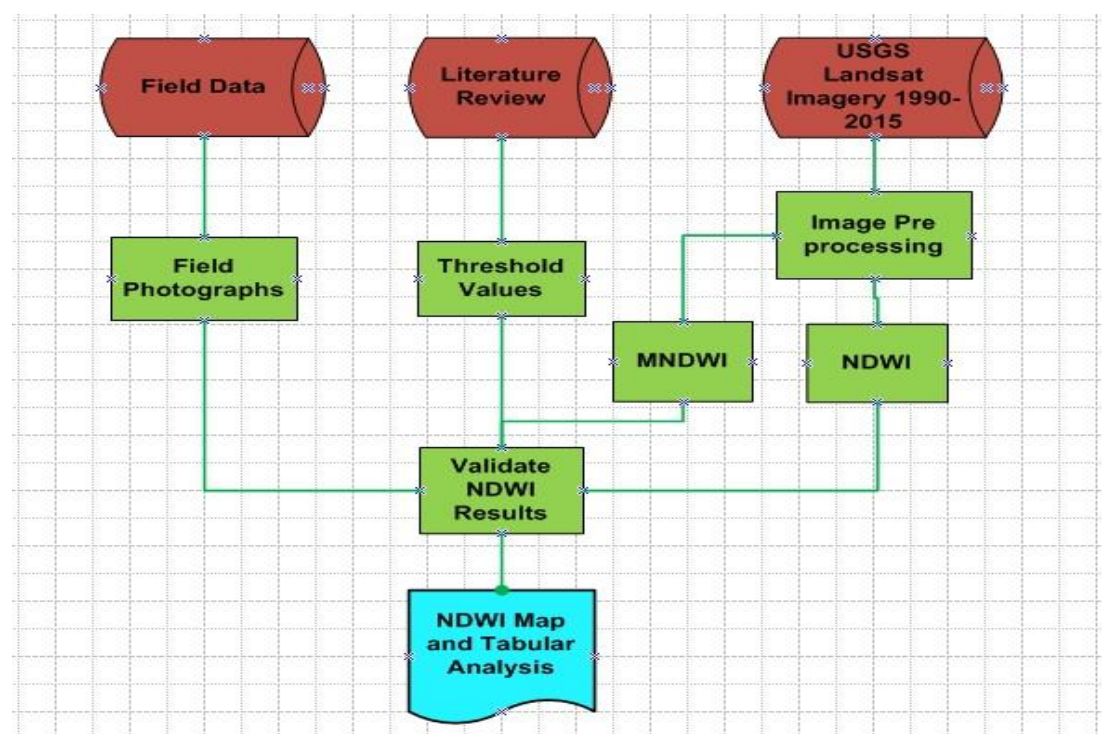

Fig. 2: Work Flow Diagram. 


\subsection{Data collection}

In this study we acquired remote sensing data like satellite images and digital elevation model DEM, field survey was conducted in coordination with local people of village and historical data about glacier in the form of report and glacial lake photographs were also taken. In this study, Landsat images were selected to assess the lake dynamics and monitor the spatial and temporal changes to investigate the situation due to availability of reasonable spatial resolution of $30 \mathrm{~m}$. Three snow and cloud free scenes of Landsat-5 Thematic Mapper (TM) for year 1991, 1996 and 2010, two scenes of Landsat-7 Enhanced Thematic Mapper Plus (ETM+) for year 2000, 2005 and one scene of Landsat-8 Operational Land Imager (OLI) for year 2015 from the month of August were acquired from USGS website (https://earthexplorer.usgs.gov).

\begin{tabular}{|c|c|c|c|c|}
\hline Satellite & Sensor & Path/Row & Year & Resolution \\
\hline Landsat-5 & $\mathrm{TM}$ & $150 / 35$ & $\begin{array}{l}1991 \\
1996 \\
2010\end{array}$ & 30 \\
\hline Landsat-7 & ETM+ & $150 / 35$ & $\begin{array}{l}2000 \\
2005\end{array}$ & 30 \\
\hline Landsat-8 & OLI & $150 / 35$ & 2015 & 30 \\
\hline
\end{tabular}

Temporal glacial lakes were identified using normalized difference water index (NDWI). Identified glacial lakes were validated through field photographs of glacier and glacial lakes. Error (shadows on lakes area in images also Rectify through visual interpretation and digitization in arc GIS environment. Digital elevation data (DEM) was acquired from USGS used to analyze the glacier lake area variation respect to different elevation.

\subsection{Methodology}

In the present research spatiotemporal distribution of water bodies in the formed of glacial lakes were delineated or mapped using normalized difference water index (NDWI). Glacial lakes have been identified with NDWI in many studies (McFeeters 1996, Ouma and Tateishi 2006)NDWI is normalized ratio index between the green and near infrared (NIR) spectral bands (McFeeters 1996).NDWI was executed through band composition of Landsat 4 - 5 TM images using band 2 (Green) and band 4 (NIR) and Landsat 8 image band 3 (Green) and band 5 (NIR) for detection of glacial lakes, at a same time depress the vegetation and other features simultaneously on the surface of Darkut glacier. The value of NDWI is lie in between -1 to +1 . Majority of water bodies existed near +1 while values near -1 show the vegetation cover and other features like soil. NDWI formula $=$ NDWI $=($ Green - Near Infrared $) /($ Green + Near Infrared $)$. The results of NDWI were validated using modified normalized difference water index (MNDWI) index, field photographs and correlation with threshold values of NDWI from literature. Image interpretation and manual editing carried out to demarcate accurate boundaries of glacial lakes in Arc GIS environment. Post processing procedures include raster to vector conversion area calculation of glacial lakes and finally developed temporal map of glacial lake. Detail of processing steps mentioned in workflow diagram (Figure 2).

\section{Results and discussion}

The spatiotemporal distribution of glacial lake during the period of $1990-2015$ was shown in (Figure 3). Temporal variability shows that, glacier lake area has been increase from 1990 to 2015. In 1990 total area of lake was 0.052 sq.km which further increased 0.0423 in 1995 than it decrease to 0.314 sq.km in 2000 due to detached of debris cover moraine from glacier tongue and it reach $0.0846 \mathrm{sq} . \mathrm{km}$ in 2005. The area gradually increased arrives at 0.1296 sq.km in 2010 and it goes up to 0.157 sq.km 2015. Overall the area/size of ghamu bar glacial lake has been increase since 1990 to 2015 .

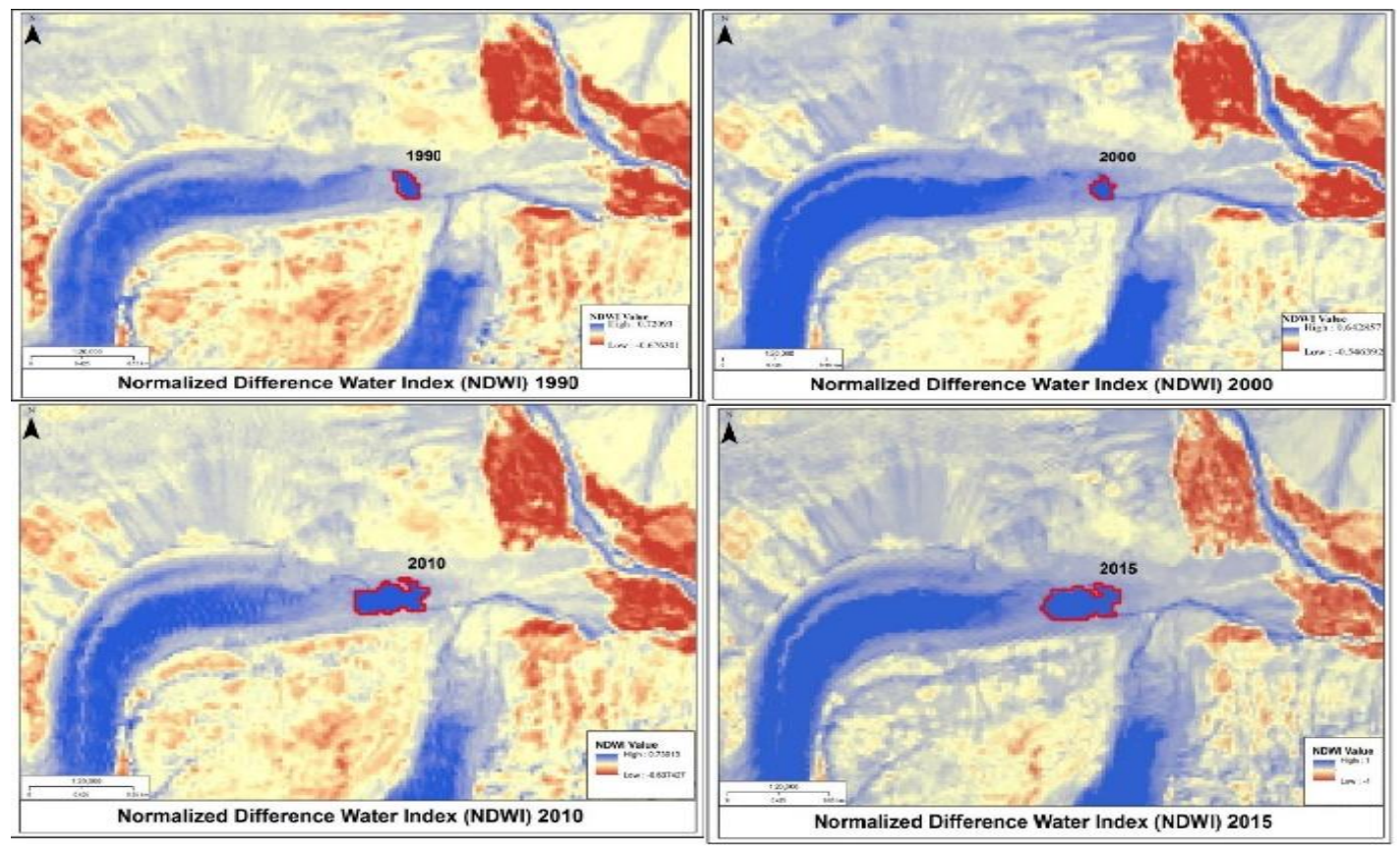

Fig. 3: Temporal View of Glacial Lake (1990 To 2015). 
The increase in glacial lake area shows that the glacier is very dynamic toward climate change. Figure:3 and graph 1 shows glacial lakes area variations in sq.km of ghamu bar lake from 1990 to 2015. Graph. 1: show the spatio- temporal changes in Ghamu Bar Lake from 1990-2015.

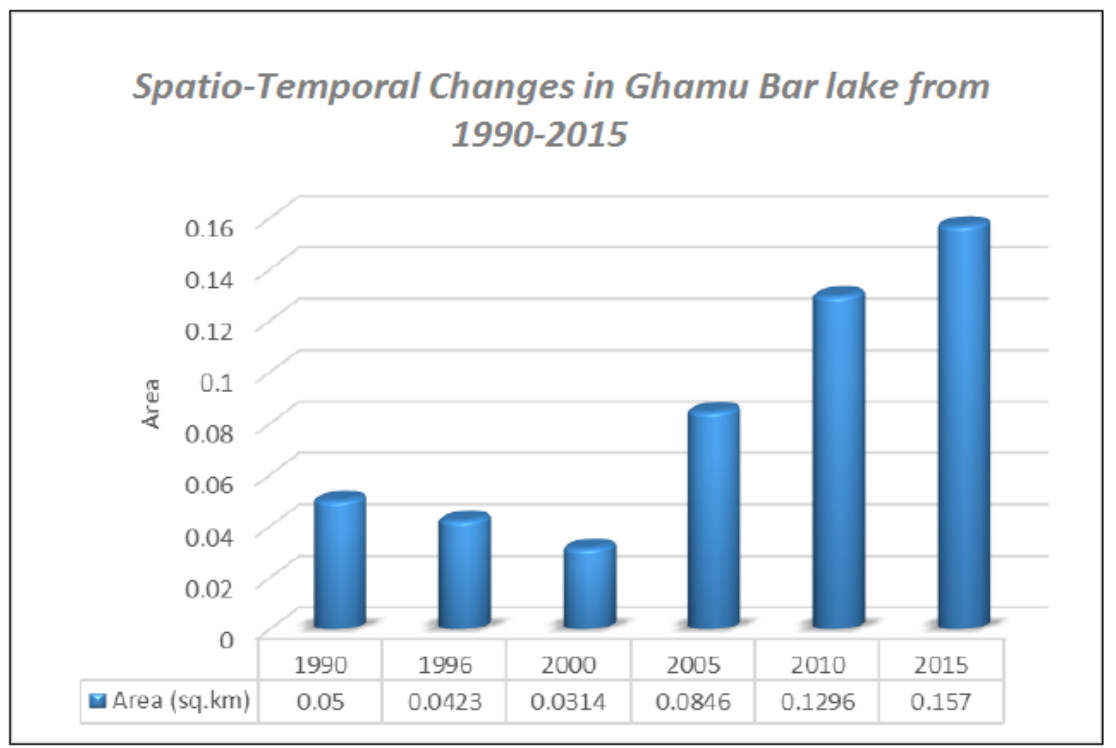

Graph. 1: Show the Spatiotemporal Changes in Glacial Lake.

Below are the field photographs of glacial lake shows the glacier tongue Darkut glacier and ghamu bar lake taken by Geologist from FOCUS Pakistan.

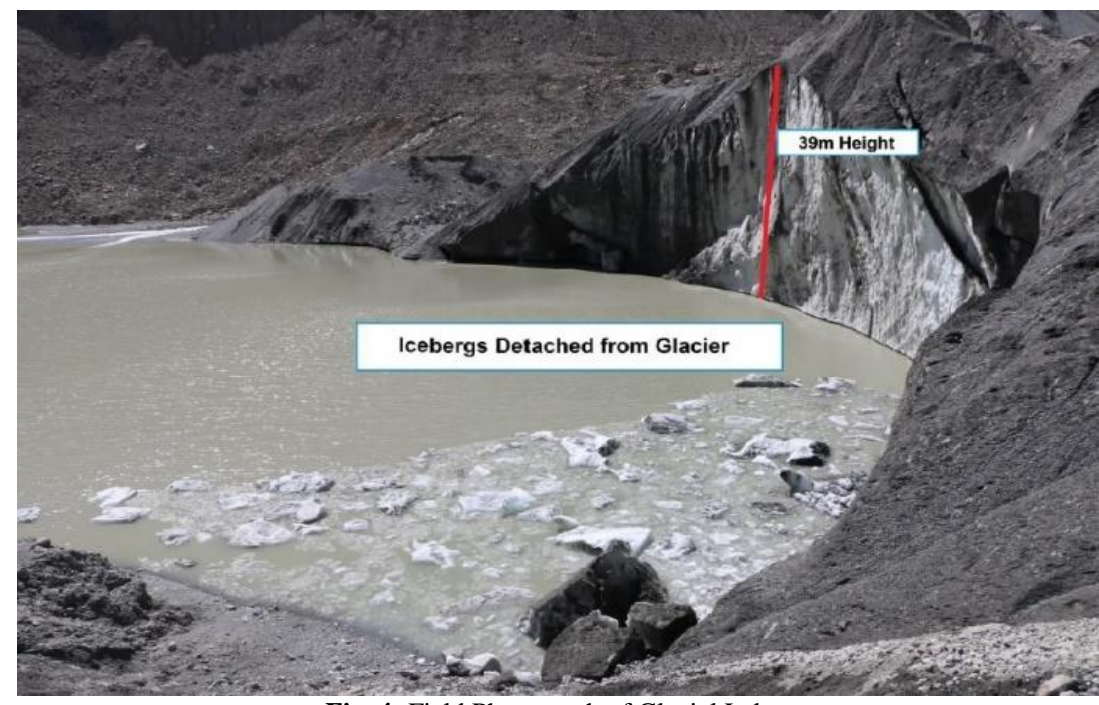

Fig. 4: Field Photograph of Glacial Lake.

\section{Conclusion and recommendation}

Remote sensing temporal application made possible to detect and monitoring of g ghamu bar glacial lake from 1990 to 2015 on high altitudes surface of Darkut glacier. The monitoring of remote glacial lake could not be possible by field investigations. In addition remote sensing is the best way to examine large area of glacier surface from accumulation zone to ablation zone. The study revealed that change of glacial lake (area and number) has been observable from temporal Landsat satellite images since 1990 to 2015. Specific recurrent temporal imaging, topographic data in form of DEM and field investigation will be valuable for understanding the dynamic of glacial lakes in detail. Remote sensing based investigation of glacier characteristic can provide location -wide information of glacier dynamics in entire ablation zone of glacier instead of point wise measurements.

Temporal variability shows that, glacier lake area has been increase from 1990 to 2015. In 1990 total area of lake was 0.052 sq, which further increased 0.0423 in 1995 than it decrease to 0.314 in 2000 due to detached of debris cover moraine from glacier tongue and it reach 0.0846 sq.km in 2005 . The area gradually increased up to 0.1296 sq.km in 2010 and it goes up to 0.157 sq.km 2015 . The overall increase in area are expanding at an accelerated rate in past two decades, indicating that Darkut glacier is more vulnerable toward climate change through increase in size and volume ofghamu bar glacial lakes. It need to vigilant to used remote sensing data and techniques for monitoring of remote glacial lakes and glacial lake outburst flood. 


\section{Acknowledgment}

The authors acknowledge that over heartiest and special gratitude to all my respected and honorable teachers of the Dept. of Geoinformatics and Earth Observation. we also thanks to Deedar karim, Waheed Anwar and Wahabudin from FOCUS Pakistan who provide temporal photographs of ghamu bar Glacial Lake.

\section{Competing interests}

The authors declare that they have no competing interests with respect to the research, authorship or publications of this article.

\section{References}

[1] Ashraf, A. et al. 2011. Identification of glacial flood hazards in Karakorum Range using remote sensing technique and risk analysis. Science Vision, 16, 71-80.

[2] Bolch, T et al 2008. Identification of glacier motion and potentially dangerous glacial lakes in the Mt. Everest region/Nepal using space borne imagery. Natural Hazards and Earth System Sciences, 8(6), 1329-1340.https://doi.org/10.5194/nhess-8-1329-2008.

[3] Frazier, P. S., \& Page, K. J. 2000. Water body detection and delineation with Landsat TM data. Photogrammetric engineering and remote sensing, 66(12), 1461-1468.

[4] Gao, H. Wang, L. Jing, L and Xu, J. 2016. An Effective Modified Water Extraction Method for Landsat-8 OLI Imagery of Mountainous Plateau Regions. IOP Conference Series: Earth and Environmental Science, (34): 12010.https://doi.org/10.1088/1755-1315/34/1/012010.

[5] Haq, M. Anul, et al 2012. "Change Monitoring of Gangotri Glacier using Remote Sensing." International Journal of Soft Computing and Engineering (IJSCE) 1.6 .

[6] Huggel, C. Haeberli, W. Kaab, A. Beiri, D and Richardson, S. 2004. An Assessment Procedure for Glacial Hazards in the Swiss Alps. Canadian Geotechnical Journal, 41(6), 1068-1083https://doi.org/10.1139/t04-053.

[7] Huggel, C., et al. 2003. Regional-scale GIS-models for assessment of hazards from glacier lake outbursts: evaluation and application in the Swiss Alps. Natural Hazards and Earth System Science, 3(6), 647-662.https://doi.org/10.5194/nhess-3-647-2003.

[8] Khanal et al., 2015. A comprehensive approach and methods for glacial lake outburst flood risk assessment, with examples from Nepal and the Trans boundary area. International journal of water resources development, 31(2), 219-237. https://doi.org/10.1080/07900627.2014.994116.

[9] Kääb, A., et al. 2002. Glacier monitoring from ASTER imagery: accuracy and applications. In Proceedings of EARSeL-LISSIG-Workshop Observing our Cryosphere from Space (Vol. 2, pp. 43-53).

[10] LU, A. X. et al 2005. 783 Study on the Fluctuations of Typical Glaciers and Lakes in the Tibetan Plateau Using Remote Sensing.

[11] Mool et al. 2001. Inventory of glaciers, glacial lakes and glacial lake outburst floods. Monitoring and early warning systems in the Hindu KushHimalayan Region: Bhutan. Inventory of glaciers, glacial lakes and glacial lake outburst floods. Monitoring and early warning systems in the Hindu Kush-Himalayan Region: Bhutan.

[12] McFeeters, S. K. (1996). The use of the Normalized Difference Water Index (NDWI) in the delineation of open water features. International journal of remote sensing, 17(7), 1425-1432.https://doi.org/10.1080/01431169608948714.

[13] Ouma, Y. O., \&Tateishi, R. (2006). A water index for rapid mapping of shoreline changes of five East African Rift Valley lakes: an empirical analysis using Landsat TM and ETM+ data. International Journal of Remote Sensing, 27(15), 3153-3181.https://doi.org/10.1080/01431160500309934.

[14] Racoviteanu, A. E., Williams, M. W., \& Barry, R. G. (2008). Optical remote sensing of glacier characteristics: a review with focus on the Himalaya. Sensors, 8(5), 3355-3383.https://doi.org/10.3390/s8053355. 